\title{
Fertilization and containers in the seedlings production and post-planting survival of Schizolobium parahyba
}

\author{
Fertilização e recipientes na produção de mudas e sobrevivência pós plantio de \\ Schizolobium parahyba
}

\author{
Gerhard Valkinir CabreiraI, Paulo Sérgio dos Santos Leles" ${ }^{\mathrm{II}}$, \\ Jorge Makhlouta Alonso ${ }^{\mathrm{III}}$, Alan Henrique Marques de Abreu ${ }^{\mathrm{IV}}$, \\ José Carlos Arthur Junior ${ }^{\mathrm{II}}$, Avner Vianna Vieira Gusmão ${ }^{\mathrm{V}}$, Nayara Franzini Lopes ${ }^{\mathrm{VI}}$
}

\begin{abstract}
Fertilization in the production of forest seedlings can vary according to the substrate, container and fertilizer used in the nursery. Controlled release fertilizers (CRF) can be applied to reduce or even to eliminate the need for top-dress fertilization. The CRF doses can vary according to the container volume, considering the different amount of substrate available for seedlings in different containers. This study aimed to evaluate the growth of Schizolobium parahyba seedlings produced in plastic tubes of 110 and 280 $\mathrm{cm}^{3}$, with different doses of CRF (15-09-12) $\left(0,3,6\right.$ e $\left.12 \mathrm{~kg} \mathrm{~m}^{-3}\right)$, as well as the seedlings survival and the initial growth after post-planting in the northern region of Rio de Janeiro state. The study was conducted using a factorial design $2 \times 4$ (tube volumes $\mathrm{x}$ CRF doses), with five repetitions for each treatment. As substrate it was used sewage sludge from urban areas, which was dried in open air beds. The growth of seedlings at nursery was evaluated at 93 days after the transplant, and the survival and initial growth at five and twelve months after planting. The Schizolobium parahyba seedlings showed higher growth in 280 $\mathrm{cm}^{3}$ tubes and responded positively to the CRF application, where the most efficient dose was $8.3 \mathrm{~kg} \mathrm{~cm}$ for this plastic tube. Twelve months after planting, seedlings from all treatments showed survival below $80 \%$, being under the standard recommended for forest restoration. The mortality of seedlings occurred in consequence of five months of water deficit in a sandy clay loam soil. Considering only nursery data, the combination of $280 \mathrm{~cm}^{3}$ plastic tubes, with the CRF dose of $8.3 \mathrm{~kg} \mathrm{~cm}^{3}$ are recommended to produce Schizolobium parahyba seedlings.
\end{abstract}

Keywords: Mineral fertilization; Sewage sludge; Plastic tube; Forest nursery

\section{Resumo}

A fertilização na produção de mudas florestais é variável de acordo com o substrato, recipiente e o tipo de fertilizante utilizados. O fertilizante de liberação controlada (FLC) pode ser utilizado visando diminuir ou mesmo eliminar a necessidade de fertilização de cobertura. A dose de FLC aplicada pode variar de acordo com o volume do recipiente, considerando a quantidade de substrato disponível para as mudas em diferentes recipientes. Este trabalho teve como objetivo avaliar o crescimento de mudas de Schizolobium parahyba produzidas com tubetes de 110 e $280 \mathrm{~cm}^{3}$ em doses crescentes de FLC (15-09-12) $(0,3,6$ e $12 \mathrm{~kg}$ $\mathrm{m}^{-3}$ ), bem como seu crescimento inicial e sobrevivência após plantio na região norte do estado do Rio de Janeiro. O estudo foi conduzido em arranjo fatorial $2 \times 4$ (recipientes x doses de FLC) com 5 repetições para cada tratamento. Como substrato foi utilizado lodo de esgoto de áreas urbanas, submetido a secagem em leitos ao ar livre. O crescimento das mudas no viveiro foi avaliado aos 93 dias após a repicagem e a

Engenheiro Florestal, MSc., Técnico de Silvicultura, Suzano S.A., Rodovia Aracruz x Barra, Km 25, CEP 29197-900, Aracruz (ES), Brasil. gerhard vc@hotmail.com (ORCID: 0000-0003-2103-3103)

II Engenheiro Florestal, Dr., Professor do Departamento de Silvicultura, Instituto de Florestas da Universidade Federal Rural do Rio de Janeiro, Rod. BR 465, Km 07, CEP 23890-000, Seropédica (RJ), Brasil. pleles@ufrrj.br (ORCID: 0000-0002-8393-6095) / josecarlosarthurjunior@gmail.com (ORCID: 0000-0002-4161-8822)

III Engenheiro Florestal, Dr., Pesquisador Autônomo, Instituto de Florestas, Universidade Federal Rural do Rio de Janeiro, Rod. BR 465, Km 07, CEP 23890-000, Seropédica (RJ), Brasil. j_makh@hotmail.com (ORCID: 0000-0002-6614-714X)

IV Engenheiro Florestal, Dr., Assistente de Projetos Especiais, Companhia Estadual de Águas e Esgotos do Rio de Janeiro, Rod. BR 465, Km 19, CEP 26280-000, Nova Iguaçu (RJ), Brasil. alan.abreu@cedae.com.br (ORCID: 0000-0002-2960-5201)

Engenheiro Florestal, Pesquisador Autônomo, Instituto de Florestas, Universidade Federal Rural do Rio de Janeiro, Rod. BR 465, Km 07, CEP 23890-000, Seropédica (RJ), avner.rj@gmail.com (ORCID: 0000-0002-1120-1399)

vı Engenheira Florestal, Doutoranda do Departamento de Engenharia Florestal, Universidade Federal de Viçosa, Rua Purdue, Campus UFV, CEP 36570-900, Viçosa (MG), Brasil. nayaraflopes@hotmail.com (ORCID: 0000-0001-9737-1155) 
sobrevivência e crescimento inicial em campo aos 5 e 12 meses após o plantio. As mudas de Schizolobium parahyba apresentaram maior crescimento em tubetes de $280 \mathrm{~cm}^{3}$ e responderam positivamente à aplicação de FLC, sendo que a dose de máxima eficiência técnica foi de $8,3 \mathrm{~kg} \mathrm{~cm}^{3}$ para esse tubete. Aos 12 meses após o plantio, mudas de todos os tratamentos apresentaram sobrevivência menor que $80 \%$, ficando abaixo do recomendado para plantios de restauração florestal. A mortalidade das mudas ocorreu devido a cinco meses de déficit hídrico em solo argilo-arenoso. Considerando apenas os dados de viveiro, a combinação de tubete de $280 \mathrm{~cm}^{3}$, com a dose de FLC de $8,3 \mathrm{~kg} \mathrm{~m}^{-3}$ são recomendados para produção de mudas de Schizolobium parahyba.

Palavras-chave: Fertilização mineral; Lodo de esgoto; Tubete; Viveiros florestais

\section{Introduction}

Commonly known in Brazil as 'guapuruvu', Schizolobium parahyba (Vell.) S.F. Blake belongs to the Fabaceae family (sub-family Caesalpinoideae), it is a fast-growing pioneer species that can reach 5 meters of height in less than 2 years after planting and more than 30 meters at the adult stage (CARVALHO, 2003; NASCIMENTO et al., 2012). The Schizolobium parahyba is likely to be one of the fastest growing tree species in the Atlantic Forest and despite presenting low demands regarding soil chemical fertility, it can exhibit superior growth when planted in fertile ground (CHINELATO et al., 2014). This species has a great economic and environmental potential, being indicated for commercial plantations, agroforestry systems, landscaping projects and especially for forest restoration and the recovery of degraded areas (CARVALHO, 2003).

The success in establishing forest stands relies on planting seedlings of good quality, which are expected to present good survival rates, fast growth and withstand the adverse conditions of the planting site, being able to compete with weed species (GOMES; PAIVA, 2006). The container type and volume, as well as the substrate physical and chemical properties are between the factors that can influence the quality of forest seedlings (LISBOA et al., 2012; ROSSA et al., 2013a).

The most used containers to produce Atlantic Forest tree seedlings are polyethylene plastic bags and polypropylene plastic tubes, which can have different sizes and volumes. Comparing both containers, the plastic tubes present the advantages of being reusable, consume less substrate, being lighter and easier to handle, improve the ergonomics of the nursery worker and allow the mechanization of some activities (GOMES; PAIVA, 2006).

Tubes with higher volumes provides more space and substrate for the seedlings, which enhances the nutrient and water content available for the plants, thereby influencing in the morphological attributes used to evaluate the quality of seedlings (BRACHTVOGEL; MALAVASI, 2010). Studying Schizolobium parahyba, Figueiró et al. (2017) concluded that seedlings produced in $300 \mathrm{~cm}^{3}$ tubes had higher growth in shoot height, root collar diameter and biomass, as well as better germination, in comparison with tubes of 50 and $110 \mathrm{~cm}^{3}$. Nevertheless, larger containers demand higher quantities of substrate, thus increasing the seedling production and transport costs (ABREU et al., 2015).

The balance between the tube volume and the seedling quality can be managed with appropriate nutrient supply through fertilization. An alternative for this purpose is to apply controlled release fertilizers (CRF), which can promote a more efficient nutrient utilization and minor leaching rate, considering that CRF will release the nutrients in the substrate gradually, synchronizing the plant physiological demands and the availability of nutrients (ROSSA et al., 2013a, b).

The main disadvantage of CRF usage is its higher acquisition cost in comparison with soluble sources. Therefore, it is necessary an adjustment of the recommended dose, seeking to optimize the management of this input for the seedling production. In Brazil, the utilization of CRF in forest nurseries can be economically viable (ROSSA et al., 2013b), some studies with Atlantic Forest species showed beneficial results of CRF application for Mimosa scabrella (STÜPP et al., 2015), Schinus terebinthifolius, Sebastiania commersoniana (ROSSA et al., 2013a). However, no

Ci. Fl., Santa Maria, v. 29, n. 4, p. 1644-1657, out./dez. 2019 
study was found for Schizolobium parahyba.

In this context, this study aimed to evaluate the seedling production as well as the post planting survival and initial growth of Schizolobium parahyba (Vell.) S.F. Blake produced in plastic tubes with different volumes and increasing doses of CRF in the substrate.

\section{Material and method}

\section{Nursery Stage}

This first study stage was carried out in the Forest Institute nursery located at the Federal Rural University of Rio de Janeiro (UFRRJ), in the city of Seropédica, Rio de Janeiro state, Brazil, from June to December of 2015. The studied species was Schizolobium parahyba (Vell.) S.F. Blake, commonly known as 'guapuruvu', this species was selected due to its ample use in forest restoration plantings.

This experiment was conducted using a completely randomized split-plot design, in a $2 \times 4$ arrangement, with two distinct tube volumes $\left(110\right.$ and $\left.280 \mathrm{~cm}^{3}\right)$ as whole plots and four CRF doses $\left(0,3,6\right.$ and $\left.12 \mathrm{~kg} \cdot \mathrm{m}^{-3}\right)$ as subplots, on a total of eight treatments with five replications each. In the $110 \mathrm{~cm}^{3}$ tube each replication consisted of ten seedlings and for $280 \mathrm{~cm}^{3}$ there were six seedlings for each replication, this distribution was done aiming to simplify the logistics of treatment dispositions in trays, which contains 96 and 54 cells, for 110 and $280 \mathrm{~cm}^{3}$, respectively.

The substrate used in the study was composed of $100 \%$ of biosolids, provided by the Water and Sewage State Company of Rio de Janeiro (CEDAE). The biosolids came from the wastewater treatment plant (WWTP) of Ilha do Governador, which uses the activated sludge process for sewage treatment. The sewage sludge generated during the wastewater treatment was submitted to dehydration in centrifuges and stabilization in open air drying beds. The selection of this material as substrates was due to the success observed in other studies that used this kind of biosolids in the seedling productions (ABREU et al., 2017; CABREIRA et al., 2017). Before the application of the CRF doses, a representative sample of the biosolids was collected for chemical and density $\left(0.72 \mathrm{~kg} \mathrm{dm}^{-3}\right)$ analyses (Table 1$)$.

Table 1 - Analysis of $\mathrm{pH}$, organic matter, total contents of macronutrients and aluminum (dry bases sample, \%) of the biosolids used as substrate for Schizolobium parahyba seedlings production.

Tabela 1 - Análise do $\mathrm{pH}$, matéria orgânica, teores totais de nutrientes e alumínio (amostra na base seca, \%) do biossólido utilizado com substrato na produção de mudas de Schizolobium parahyba.

\begin{tabular}{rccccccc}
\hline $\mathbf{p H}$ & $\mathbf{N}$ & $\mathbf{P}$ & $\mathbf{K}$ & $\mathbf{C a}$ & $\mathbf{M g}$ & $\mathbf{A l}$ & $\mathbf{O M}$ \\
\hline $\mathbf{5 . 5}$ & 1.94 & 0.81 & 0.19 & 1.59 & 0.19 & 2.72 & 35.3 \\
\hline
\end{tabular}

Where: $\mathrm{pH}$ in water: Potentiometry; N: Kjeldahl; P: Colorimetric Method; K: Flame Photometry; Ca, Mg e Al: Atomic Absorption Spectrometry; Organic matter (OM): Gravimetric

The fertilizer doses were 3,6 and $12 \mathrm{~kg} \mathrm{~m}^{3}$ of CRF (N-P-K 15-09-12) in the substrate, there were also a control treatment without any fertilizer. The CRF used in the study was encased in a coating of permeable organic resin and contained $15 \% \mathrm{~N}, 09 \%$ of $\mathrm{P}_{2} \mathrm{O}_{5}, 12 \%$ of $\mathrm{K}_{2} \mathrm{O}, 1 \%$ of $\mathrm{Mg}$, $2,3 \%$ of $\mathrm{S}, 0,05 \%$ of $\mathrm{Cu}, 0,45 \%$ of $\mathrm{Fe}, 0,06 \%$ of $\mathrm{Mn}$ and $0,02 \%$ of Mo. The manufacturer of the CRF states that the complete formula nutrient release occurs within eight to nine months.

After homogenizing the fertilizer doses with the substrate, the tubes were filled manually 
and placed in trays, according to the corresponding treatment. The seeding took place in an open-air seedbed. Three weeks after sowing the saplings were transplanted into the tubes. As a protection measure, during the first 20 days after transplanting, the seedlings were kept under a shade house with $50 \%$ of light block. The seedlings were irrigated twice a day, in the beginning of the morning and late afternoon. During the entire experiment, undesired plants were removed manually from the container of each seedling.

The shoot height was first measured at 30 days after transplanting, with a graduated ruler $(\mathrm{cm})$, and subsequently every 12 days, until 93 days, when seedlings were taken to the planting site. At 93 days after transplanting, the root collar diameter was also measured with a digital caliper (mm).

The five seedlings closest to shoot height average for each treatment were selected to evaluate leaf area (LA), shoot dry matter (SDM) and root dry matter (RDM). Leaf area was assessed using a LICOR-3600 meter. The seedlings shoot and root were separated, placed into identified paper bags and allocated inside a forced air oven at $65^{\circ} \mathrm{C}$ for 72 hours, then the material was weighted in a precision scale for determining SDM and RDM.

Once dry matter was weighed, the shoot samples of each seedling were milled using a knife mill. The material was identified, placed in covered plastic recipients and sent to macronutrient chemical analyses. It was evaluated the total contents of $\mathrm{P}, \mathrm{K}, \mathrm{Ca}$ and $\mathrm{Mg}$ according to the methodology proposed by Embrapa (2009), with nitric-perchloric acid digestion of the material and the determination of each nutrient content by optical emission spectrometry (ICP-OES). The total content of $\mathrm{N}$ was determined with solid samples evaluated in CHNS elemental analyzer (EMBRAPA, 2009). The accumulation of nutrients in seedlings was calculated multiplying the content of each nutrient by the total dry mass of each seedling.

The homogeneity of variances was tested for each variable evaluated in the last measurement using the Bartlett test with 5\% probability. All measured variables were submitted to analysis of variance, when significance was detected between plastic tubes the t-test was performed, considering $5 \%$ probability. In the case of significance between the doses, data were submitted to regression analysis and verified by Graybill model identity test. The same was done for the analysis of shoot height over time, when the same regression model was adjusted for distinct fertilizer doses. The statistical analysis was performed using the software 'Sistema de Análise Estatística e Genética’ (SAEG).

\section{Field Stage}

Planting took place at the Ecological Station of Guaxindiba, located in São Francisco do Itabapoana city, Rio de Janeiro state. The area was previously cultivated with sugar cane plantation and is currently under a forest restoration process. The area has a plain topography, with average height of 25 meters above sea level. The soil is classified as Ultisol with a sandy clay loam, composed by $60 \%$ of sand, $38 \%$ of clay and $2 \%$ of silt. The climate in the region is Cwa (subtropical with dry winters and hot summers) according to the Köppen (1936) classification, on which the rain predominates from December to March.

To provide a better description of the area, the monthly average water balance was calculated using the Thornthwaite and Mather (1955) method, considering a historical series of 20 years (from January 1996 to November 2016). A spreadsheet proposed by Sentelhas; Pereira; Marin (1998) was used, filled with data from the closest weather station, located in Campo dos Goytacazes - RJ, considering an available water capacity (AWC) of the soil of $100 \mathrm{~mm}$, which is presented in Figure 1. 
Figure 1 - Average monthly water balance for the historical series of the planting site, located in the Guaxindiba Ecological Station, São Francisco do Itabapoana - RJ.

Figura 1 - Média do balanço hídrico mensal para a série histórica do local de plantio na Estação Ecológica da Guaxindiba, São Francisco do Itabapoana - RJ.

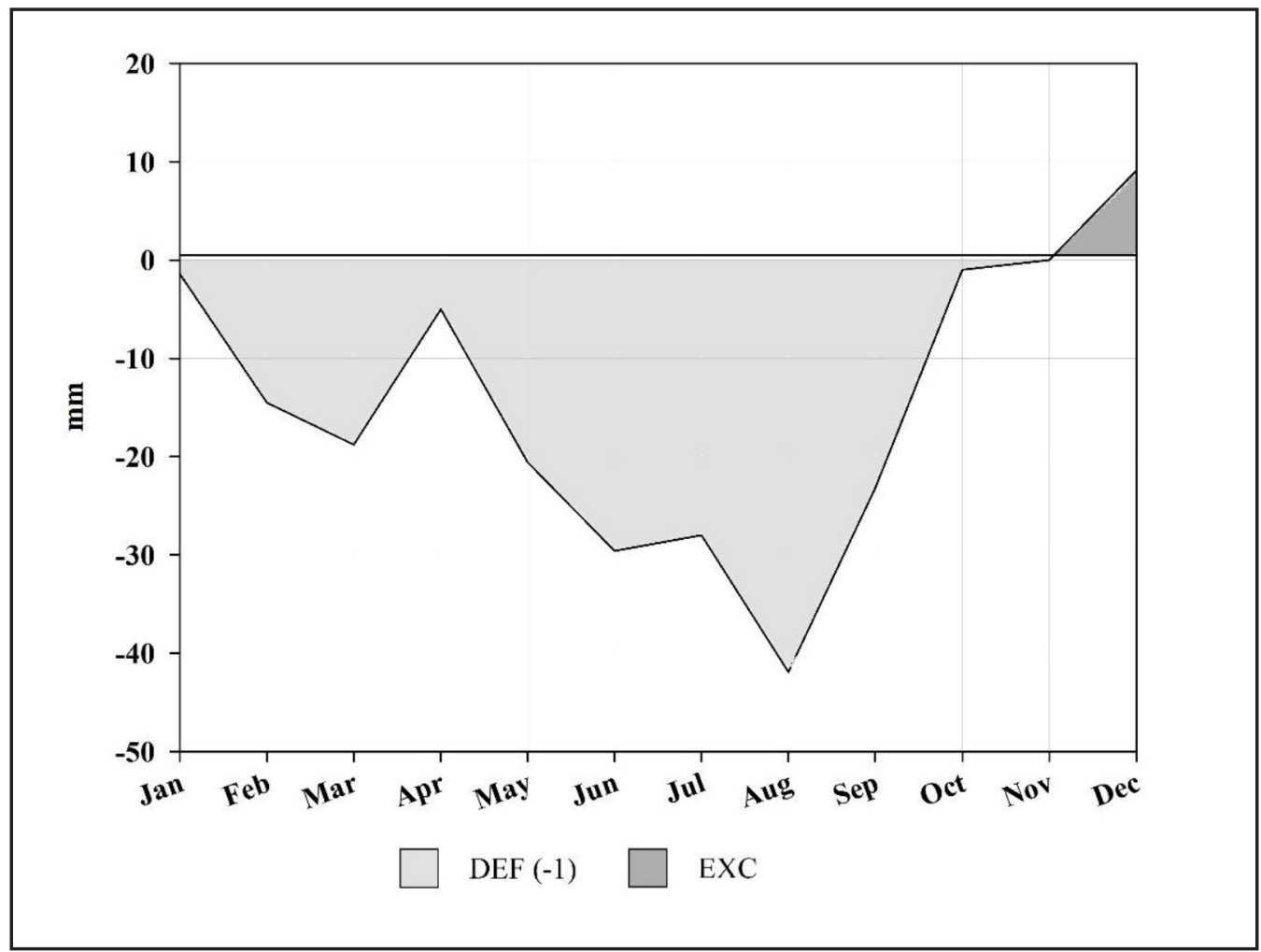

Source: Cabreira et al. (2019)

Planting was done in December 2015, using a spacing of $3 \times 2 \mathrm{~m}$ and planting pits with dimensions of $50 \times 50 \mathrm{~cm}$. Due to the experimental area homogeneity, the selected design was the completely randomized, considering each seedling as one repetition.

The treatments were the same tested in the nursery, for each of them 20 seedlings with shoot height near the average were planted. The seedlings were allocated in 20 rows, intercalating one 'guapuruvu' seedling with three of other species. On every row, there was one seedling of each treatment, summing up 20 repetitions per treatment. After planting, all seedlings were manually irrigated with approximately 4 liters of water and the Schizolobium parahyba seedling shoot heights were measured. No fertilization was done.

According to data collected in a pluviometer located near the experimental area, between December $1^{\text {st }}$ of 2015 to November $30^{\text {th }}$ of 2016 the accumulated precipitation was $891 \mathrm{~mm}$. During the first five months (; December, January, February, March and April) after planting there were precipitations of $137.5 ; 285.7 ; 131.7 ; 101.5$ and $49.9 \mathrm{~mm}$, respectively with $10,18,6,8$ and 5 days of rain on each month. During other months the amount of rain was very low.

The evaluations consisted of seedlings survival rate at 5 and 12 months after planting. On both occasions, the shoot height and the ground diameter (GD) were determined only at 12 months.

Normality and homogeneity of the residuals were evaluated for shoot height and GD. Results were submitted to analysis of variance. For all analysis, the software used was the 'Sistema de Análise Estatística e Genética’ (SAEG). 


\section{Results and discussion}

\section{Nursery stage}

Considering the five measures of shoot height done at 30, 42, 54, 66 and 93 days, it was verified linear growth of the Schizolobium parahyba seedlings for both tubes sizes and in the different fertilization doses (Figures 2A and 2B). Furthermore, it was observed that the use of fertilizer accelerated seedlings growth, according to the identity model test it was detected significant difference between the equations adjusted for each CRF dose in both tubes volumes.

\section{Figure 2 - Average shoot height during the production time of Schizolobium parahyba seedlings in $110 \mathrm{~cm}^{3}(\mathrm{~A})$ and $280 \mathrm{~cm}^{3}(\mathrm{~B})$ plastic tubes, with increasing CRF doses. "significant at $5 \%$ level according to model identity test.}

Figura 2 - Média de altura durante o tempo de produção das mudas de Schizolobium parahyba em tubetes de $110 \mathrm{~cm}^{3}$ (A) e $280 \mathrm{~cm}^{3}$ (B) com doses crescentes de FLC. *significativo ao nível de $5 \%$ pelo teste de indentidade de modelos.

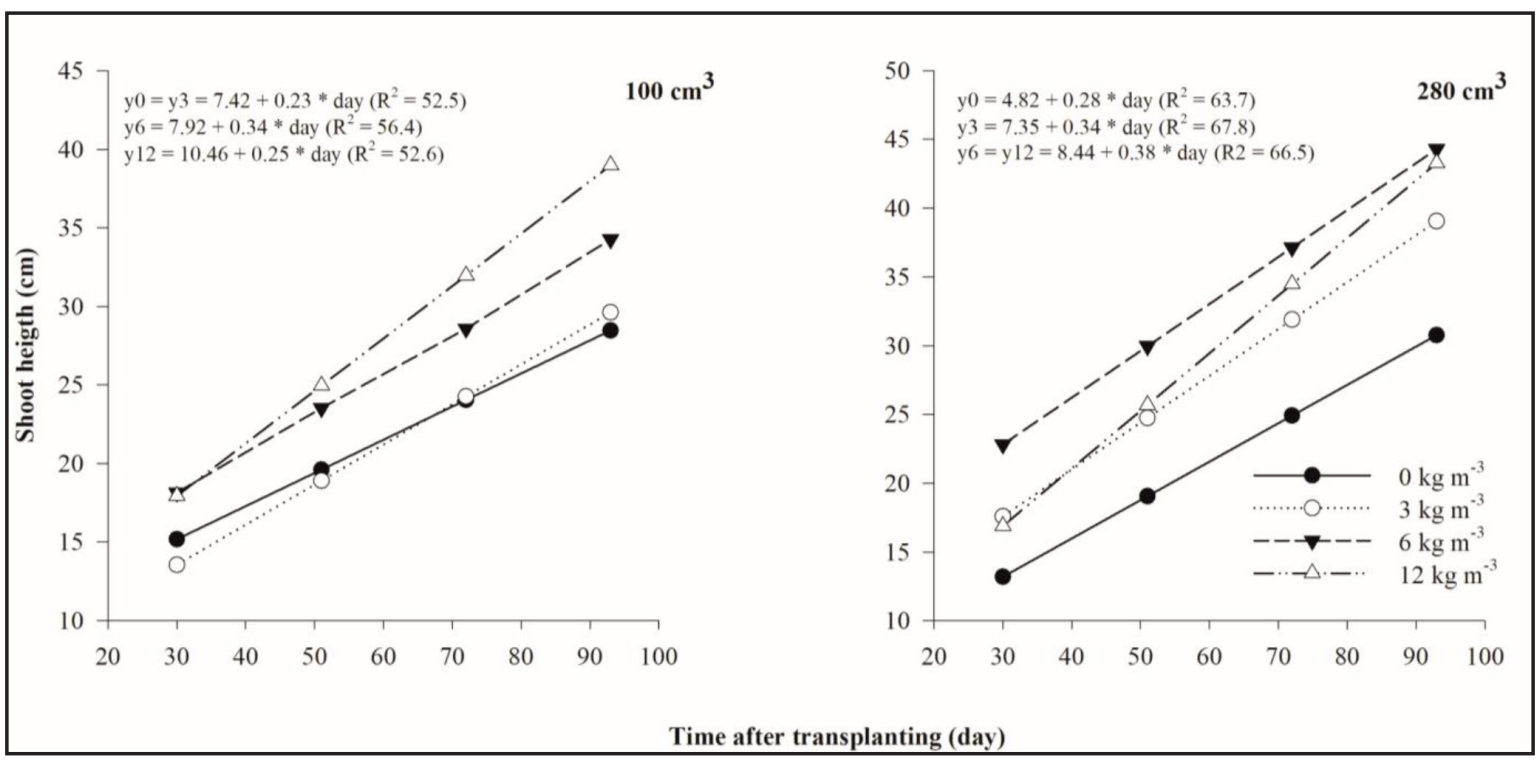

Source: Cabreira et al. (2019)

For the $110 \mathrm{~cm}^{3}$ plastic tubes it was verified by the model identity test that seedlings which received a $12 \mathrm{~kg} \mathrm{~m}^{-3}$ dose were superior, followed by the $6 \mathrm{~kg} \mathrm{~m}^{-3}$ treatment. Seedlings of control (without fertilizer) and $3 \mathrm{~kg} \mathrm{~m}^{-3}$ presented statistically identical models and inferior to other treatments (Figure 2A). Considering the seedlings produced in $280 \mathrm{~cm}^{3}$ tubes, treatments with 6 and $12 \mathrm{~kg} \mathrm{~m}^{-3}$ of CRF presented identical models, which were superior than the $3 \mathrm{~kg} \mathrm{~m}^{-3}$ dose (Figure 2B). Seedlings that did not received fertilizer presented the lowest values.

Contrasting results between both tubes could possibly be related to the volume of substrate and the nutrient availability. Due to smaller volume in the $110 \mathrm{~cm}^{3}$ tube the amount of substrate, and consequently, of nutrients available per plant is lower (LELES et al., 2006), which may cause a greater response of seedlings to mineral fertilization, justifying the higher growth observed in $12 \mathrm{~kg} \mathrm{~m}^{-3}$ dose. Seedlings also responded to fertilization in the $280 \mathrm{~cm}^{3}$ tubes, however only until the $6 \mathrm{~kg} \mathrm{~m}^{-3}$ dose.

The shoot height is one of the most used parameters to evaluate quality and to determine the correct time for planting forest seedlings. For Atlantic Forest species, Moraes et al. (2013) 
suggests that seedlings are ready to be planted when shoot height reaches 25 to $30 \mathrm{~cm}$. In this study, seedlings in $280 \mathrm{~cm}^{3}$ tubes combined with the higher dose of CRF reached the suggested height at 50 days after transplanting, more than a month before seedlings in the same container and no fertilization. In the $110 \mathrm{~cm}^{3}$ tubes the results were similar, with seedlings growing faster with increasing doses of CRF. Results showed that for Schizolobium parahyba seedlings produced in tubes, using CRF reflects positively on shoot height, presenting a management choice to accelerate and improve the production process. It is possible to observe in all treatments that, at 93 days after transplanting, seedlings were still on a linear growth pattern indicating that a growth climax was still to be reached (Figure 2).

It was observed in Table 2 that seedlings had distinct averages for all the evaluated parameters, considering both sources of variation (tube volume and doses of CRF) and their interaction. The relation between the tube volume and the fertilizer dose was not significant only to RDM.

Table 2 - Analysis of variance for morphological parameters of Schizolobium parahyba seedlings, at 93 days after transplanting, produced in different plastic tube volumes and increasing controlled release fertilizer doses.

Tabela 2 - Análise da variância de parâmetros morfológicos de mudas de Schizolobium parahyba, aos 93 dias após a repicagem, produzidas em diferentes volumes de tubetes e doses crescentes de fertilizante de liberação lenta.

\begin{tabular}{lcccccc}
\hline Source of Variation & DF & Height $(\mathbf{c m})$ & RCD $(\mathbf{m m})$ & Leaf Area $\left(\mathbf{c m}^{2}\right)$ & SDM $(\mathbf{g})$ & RDM $(\mathbf{g})$ \\
\hline Tube & 1 & $437.6^{*}$ & $16.38^{*}$ & $33528^{*}$ & $35.19^{*}$ & $2.19^{*}$ \\
Error A & 8 & 16.3 & 0.49 & 676 & 1.62 & 0.48 \\
Dose & 3 & $256.0^{*}$ & $1.57^{*}$ & $14651^{*}$ & $11.65^{*}$ & $1.47^{*}$ \\
Tube*Dose & 3 & $30.3^{*}$ & $1.61^{*}$ & $4821^{*}$ & $6.12^{*}$ & $0.24^{\mathrm{ns}}$ \\
$\begin{array}{l}\text { Error B } \\
\text { Where: RCD = root collar diameter; SDM }\end{array}$ & 24 & 3.0 & 0.21 & 1022 & 1.29 & 0.30 \\
degrees of freedom; * & significant at 10\% level by t-test; ns not significant at 10\% level by t-test.
\end{tabular}

It is observed that seedlings produced in $110 \mathrm{~cm}^{3}$ tubes, at 93 days after transplanting, demonstrated linear growth for height and leaf area in relation to increasing CRF doses to the substrate (Figure 3), indicating that seedlings could still respond to larger doses of fertilizer. This behavior can be explained by the smaller content of nutrients available in such tube of reduced volume, this way, the higher the fertilizer dose is, the higher the response of plants is. There was no equation adjustment for root collar diameter and shoot dry matter, showing that in this tube fertilization did not interfere in these two parameters.

Concerning seedlings produced in $280 \mathrm{~cm}^{3}$ tubes, quadratic equations were adjusted for height and diameter and linear for leaf area and shoot dry matter (Figure 3). The results for height and diameter show that plants have a maximum biological growth and do not grow on the same proportion as the fertilizer applications. According to the law of diminishing increments, the increase in production with the application of fertilizers is not linear, in higher doses, the production increments tend to decrease and even be prejudicial to plants (RAIJ et al., 2001), like it was observed in the present study. According to the equations, the most efficient doses of CRF, respectively for height and diameter, were 8.6 and $8.0 \mathrm{~kg} \mathrm{~m}^{3}$ using biosolids as substrate. On average terms, this represents a CRF recommendation of $8.3 \mathrm{~kg} \mathrm{~m}^{3}$ for this substrate, considering just growth characteristics during nursery stage. 
Figure 3 - Regression equations for shoot height, root collar diameter, leaf area and shoot dry matter (SDM) of Schizolobium parahyba seedlings produced with increasing controlled release fertilizer doses, in two different plastic tube volumes, at 93 days after transplanting. *significant at $1 \%$ level according to model identity test.

Figura 3 - Equações de regressão para altura, diâmetro, área foliar e matéria seca da parte aérea (SDM) de mudas de Schizolobium parahyba produzidas com doses crescentes de fertilizante de liberação controlada, em tubetes de dois volumes aos 93 dias após a repicagem. *significativo ao nível de $1 \%$ pelo teste de identidade de modelos.

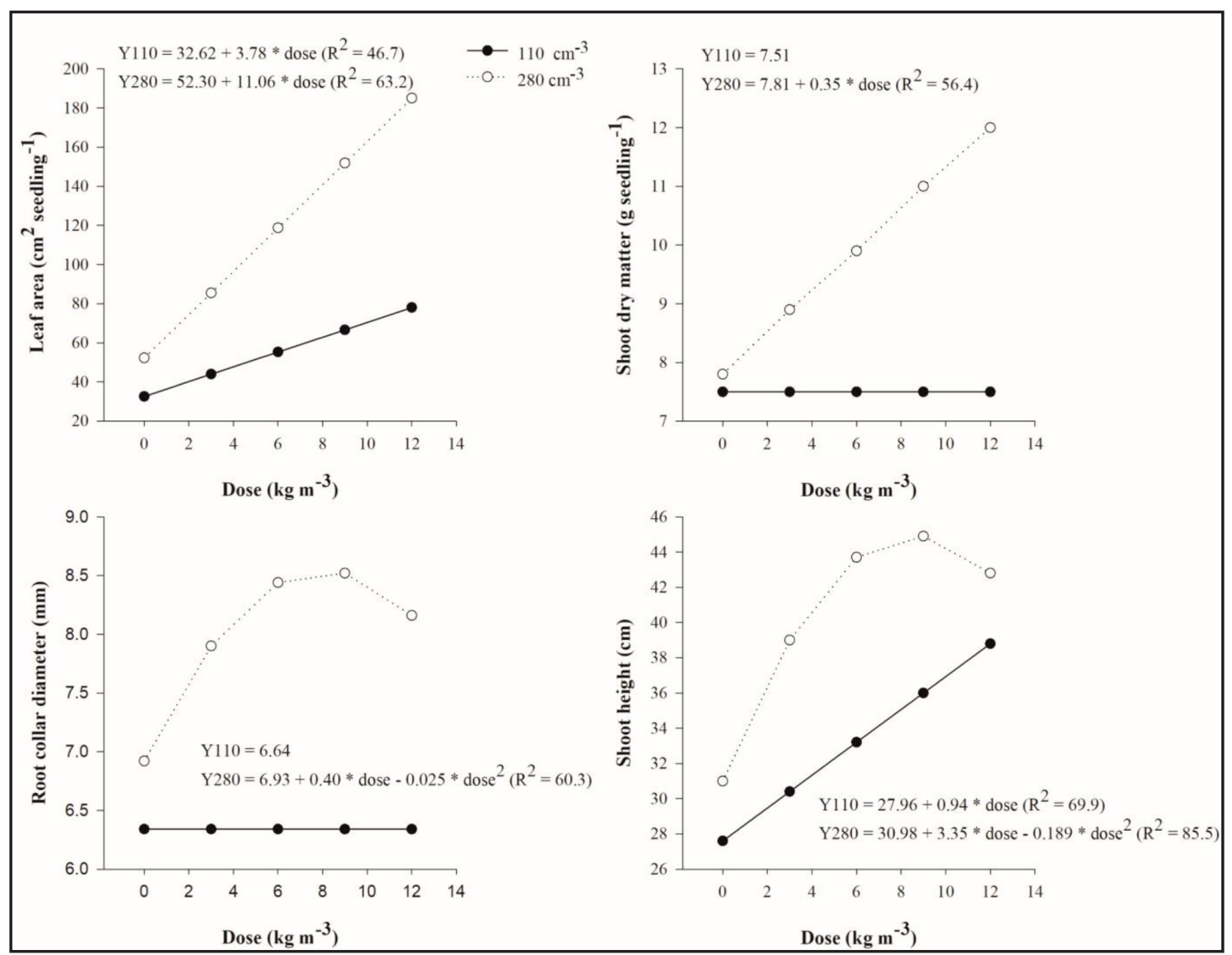

Source: Cabreira et al. (2019)

In similar studies, alsowith Atlantic Forest species, Rossa etal. (2013a) analyzed CRF doses from 0 to $10 \mathrm{~kg} \mathrm{~m}^{3}$ of substrate (composed mainly of pine bark) in $180 \mathrm{~cm}^{3}$ tubes, for Schinus terebinthifolius seedlings it was verified a most efficient dose of $9.48 \mathrm{~kg} \mathrm{~m}^{-3}$ and for Sebastiania commersoniana of 5.54 $\mathrm{kg} \mathrm{m}^{-3}$. For Mimosa scabrella seedlings, in 110 and $180 \mathrm{~cm}^{3}$ tubes and CRF doses from 0 to $9 \mathrm{~kg} \mathrm{~m}$ of substrate (composed mainly of peat), Stüpp et al. (2015) observed most efficient doses of 7.70 and $6.25 \mathrm{~kg} \mathrm{~m}^{-3}$, for 110 and $180 \mathrm{~cm}^{3}$ tubes respectively. The result of the present study, together with the quoted ones, suggests that the ideal doses of CRF can vary according to the substrate, recipient and the species.

In the management of nurseries with high diversity of species, like the ones producing Atlantic Forest species for restoration projects, a distribution of species in groups, according with their nutritional needs, can be beneficial both for the quality of seedlings and for more efficient fertilizer application. As observed for Prunus brasiliensis in Scheer; Carneiro; Santos (2012) and for Anadenanthera colubrina in Scheer et al. (2012), the nutrients contained in the biosolids used as substrates were enough to produce good quality seedlings. However, the application of CRF improved their growth, being recommended the use of $2.7 \mathrm{~kg} \mathrm{~m}^{3}$ in plastic tubes with $110 \mathrm{~cm}^{3}$. This dose is 
lower than the ones suggested by the results of the present study, showing that $S$. parahyba may have a superior nutritional demand than species evaluated by cited authors.

In substrates with less fertility, the gain with CRF application could be more expressive, like in Rossa et al. (2013b), who analyzed doses of CRF (NPK 13-06-13) from 0 to $10 \mathrm{~kg} \mathrm{~m}^{3}$ of a low fertility substrate (60\% pine bark, $30 \%$ sifted organic compound and $10 \%$ of vermiculite) for Schizolobium amazonicum, a species very similar to the one evaluated in the present study. The authors recommended doses between 8.65 and $12.07 \mathrm{~kg} \mathrm{~m}^{3}$ (average of $10.36 \mathrm{~kg} \mathrm{~m}^{-3}$ ), which were higher than the recommendation of this study. The difference between both studies could be attributed to the fertility of substrates and tube volume, which in Rossa et al. (2013b) was of $180 \mathrm{~cm}^{3}$.

In the $110 \mathrm{~cm}^{3}$ tube, with increasing doses of CRF there was little gain in height and none in diameter. This result suggests that fertility was not a limiting factor for the plants, other aspects of the substrate, like its physical characteristics, may have limited growth. The increase of biosolids proportion in the substrate can lead to higher density and lower aeration (GUERRINI AND TRIGUEIRO 2004), considering that in the present study the substrate was $100 \%$ biosolids, this could have affected the growth of seedlings. However, this problem was not observed in the $280 \mathrm{~cm}^{3}$ tubes, which have $154 \%$ more volume for substrate, suggesting that Schizolobium parahyba seedlings may need more space for its initial growth, and the $110 \mathrm{~cm}^{3}$ tubes do not offer enough space for the roots, thus limiting the seedling growths.

It is possible to observe that in the control treatment (without fertilization) there was no difference between tube volumes for any growth variable measured (Table 3). However, when CRF was applied, in general terms, seedlings produced in $280 \mathrm{~cm}^{3}$ tubes presented superior growth compared to seedlings produced in $110 \mathrm{~cm}^{3}$ tubes, except for root dry matter (RDM) that only showed significant difference at $3 \mathrm{~kg} \mathrm{~m}^{-3}$ dose. The superior growth of forest species in plastic tubes of higher volumes is also reported in other studies, like Ferraz and Engel (2011) with three species, Hymenaea courbaril, Tabebuia chrysotricha e Parapiptadenia rigida, comparing tubes of 50,110 and $300 \mathrm{~cm}^{3}$, as well as in Stüpp et al. (2015), with Mimosa scabrella seedlings in tubes of 110 and $180 \mathrm{~cm}^{3}$. For Schizolobium parahyba seedlings, Figueiró et al. (2017), comparing tubes of 50, 110 and $300 \mathrm{~cm}^{3}$ verified higher growth in height and diameter in the larger volume plastic tube.

Table 3 - Comparison between mean values of morphological parameters for Schizolobium parahyba seedlings, at 93 days after transplanting, produced in different plastic tube volumes and increasing controlled release fertilizer doses.

Tabela 3 - Comparação entre as médias dos parâmetros morfológicos de mudas de Schizolobium parahyba, aos 93 dias após a repicagem, produzidas em diferentes volumes de tubetes e doses crescentes de fertilizante de liberação lenta.

\begin{tabular}{lccccc}
\hline \multicolumn{1}{c}{ CRF Dose $\left(\mathbf{k g ~ m}^{-3}\right)$} & $\mathbf{0}$ & $\mathbf{3}$ & $\mathbf{6}$ & $\mathbf{1 2}$ \\
\hline \multirow{2}{*}{ Height $(\mathbf{c m})$} & $110 \mathrm{~cm}^{3}$ & 28.2 & 29.2 & 34.3 & 38.9 \\
& $280 \mathrm{~cm}^{3}$ & $30.8^{\mathrm{ns}}$ & $38.9^{*}$ & $43.8^{*}$ & $42.7^{*}$ \\
\hline $\begin{array}{l}\text { Root collar diameter } \\
(\mathbf{m m})\end{array}$ & $110 \mathrm{~cm}^{3}$ & 6.7 & 6.0 & 6.5 & 7.1 \\
\hline \multirow{2}{*}{ Leaf area $\left(\mathbf{c m}^{2}\right)$} & $280 \mathrm{~cm}^{3}$ & $6.9^{\mathrm{ns}}$ & $7.8^{*}$ & $8.5^{*}$ & $8.2^{*}$ \\
\hline \multirow{2}{*}{ Shoot dry matter $(\mathrm{g})$} & $110 \mathrm{~cm}^{3}$ & 33 & 29 & 76 & 71 \\
\hline \multirow{2}{*}{ Root dry matter $(\mathbf{g})$} & $280 \mathrm{~cm}^{3}$ & $47^{\mathrm{ns}}$ & $98^{*}$ & $111^{*}$ & $186^{*}$ \\
\hline
\end{tabular}

Where: ${ }^{*}$ significant at $1 \%$ of probability. ${ }^{\text {ns }}$ not significant at $1 \%$ of probability. 
Considering that biosolids, used in this study as substrate, are rich in nutrients and organic matter as can be observed in Table 1, the higher growth of seedlings in $280 \mathrm{~cm}^{3}$ tubes can be due to the larger substrate volume, which provides a greater supply of nutrients, water and space for the root system development. According to Lisboa et al. (2012) and Leles et al. (2006), tubes of smaller volume restrict the root system growth and, as plants tend to have a balanced development, this interferes on other morphological parameters. The smaller the tube is, the smaller the availability of nutrients will be and the shorter the time elements will remain in the substrate, considering both the plant consumption and the leaching caused by irrigation.

According to data showed in Table 4, the macronutrients content in the aerial part of the plants increased along with the growing doses of CRF, except for Ca that decreased and for $\mathrm{Mg}$ that did not present a pattern. The content of macronutrients accumulated in the plant tissues increased with the growing doses of CRF for all nutrients, except for $\mathrm{Ca}$ and $\mathrm{Mg}$ (Table 4). The content of nutrients was a little higher in the seedlings produced in $280 \mathrm{~cm}^{3}$ plastic tubes, what can be possibly explained by the higher availability of substrate, and consequently nutrient availability in the larger tube. Overall, the accumulation of $\mathrm{N}, \mathrm{P}$ and $\mathrm{K}$ on the leaves was superior when CRF was applied in comparison with the seedlings produced without fertilization.

Table 4 - Mean content (above) and accumulated (under) macronutrients in the aerial part of Schizolobium parahyba seedlings produced in two volumes of plastic tubes and increasing doses of controlled release fertilizer at 93 days after transplanting.

Tabela 4 - Teores médios (acima) e acúmulo (embaixo) de macronutrientes na parte aérea de mudas de Schizolobium parahyba produzidas em dois volumes de tubetes e doses crescentes de fertilizante de liberação controlada aos 93 dias após a repicagem.

\begin{tabular}{|c|c|c|c|c|c|c|}
\hline \multirow[t]{2}{*}{ Tube } & \multirow{2}{*}{$\begin{array}{c}\text { Dose } \\
\left(\mathbf{k g ~ m}^{-3}\right) \\
\end{array}$} & $\mathbf{N}$ & $\mathbf{P}$ & $\mathbf{K}$ & $\mathrm{Ca}$ & Mg \\
\hline & & \multicolumn{5}{|c|}{ Mean content $\left(\mathrm{g} \mathrm{kg}^{-1}\right)$} \\
\hline \multirow{4}{*}{$110 \mathrm{~cm}^{3}$} & 0 & 15.8 & 1.8 & 4.9 & 24.0 & 0.13 \\
\hline & 3 & 18.4 & 2.4 & 7.3 & 25.4 & 0.16 \\
\hline & 6 & 17.3 & 2.0 & 6.9 & 27.2 & 0.14 \\
\hline & 12 & 24.0 & 2.8 & 11.0 & 16.7 & 0.15 \\
\hline \multirow{6}{*}{$280 \mathrm{~cm}^{3}$} & 0 & 18.5 & 1.8 & 6.9 & 29.6 & 0.16 \\
\hline & 3 & 24.0 & 2.3 & 9.1 & 23.7 & 0.15 \\
\hline & 6 & 25.3 & 2.3 & 9.0 & 28.2 & 0.14 \\
\hline & 12 & 26.2 & 2.1 & 8.2 & 19.2 & 0.14 \\
\hline & & $\mathrm{N}$ & $\mathrm{P}$ & K & $\mathrm{Ca}$ & $\mathrm{Mg}$ \\
\hline & & \multicolumn{5}{|c|}{ Accumulated $\left(\mathrm{mg}\right.$ seedling $\left.{ }^{-1}\right)$} \\
\hline \multirow{4}{*}{$110 \mathrm{~cm}^{3}$} & 0 & 123 & 14 & 38 & 187 & 1.01 \\
\hline & 3 & 129 & 17 & 51 & 178 & 1.12 \\
\hline & 6 & 140 & 16 & 56 & 220 & 1.13 \\
\hline & 12 & 197 & 23 & 90 & 137 & 1.23 \\
\hline \multirow{4}{*}{$280 \mathrm{~cm}^{3}$} & 0 & 146 & 14 & 55 & 234 & 1.26 \\
\hline & 3 & 209 & 20 & 70 & 206 & 1.31 \\
\hline & 6 & 253 & 23 & 79 & 282 & 1.40 \\
\hline & 12 & 317 & 25 & 99 & 232 & 1.69 \\
\hline
\end{tabular}


The chemical composition of the biosolids (Table 1) and of the CRF used in this study also influenced the results for $\mathrm{Ca}$ and $\mathrm{Mg}$ observed in the plants tissues. While the CRF had no $\mathrm{Ca}$ and $1 \%$ of $\mathrm{Mg}$ in its composition, the biosolids was rich in $\mathrm{Ca}(1.54 \%)$ and poor in $\mathrm{Mg}(0.19 \%)$. This justifies the increasing accumulation of $\mathrm{Mg}$ in the plant tissues that occurred with the increasing doses of CRF. Regarding $\mathrm{Ca}$, there was no addition via fertilization of this nutrient, so the content was equal in all treatments.

The average macronutrient content followed the order $\mathrm{Ca}>\mathrm{N}>\mathrm{K}>\mathrm{P}>\mathrm{Mg}$, this pattern was observed for both containers. The elevated $\mathrm{Ca}$ content can be related to the structural role that this element displays in the plant, accumulating mainly in the cell wall (TAIZ AND ZEIGER, 2009). High concentrations of $\mathrm{Ca}$ in the plants tissue can be detected when there is omission of $\mathrm{K}$, due to competitive inhibition between these two nutrients (MARSCHNER, 1995). This effect can explain the results verified in the present study, considering the low contents of $\mathrm{K}$ found in the biosolid composition (Table 1). Also, for both tubes, the lowest Ca concentrations were observed in treatments with higher CRF doses, therefore suggesting that the fertilization supplied more $\mathrm{K}$ for the plants, lowering Ca absorption.

\section{Field Stage}

At five months after planting, survival rates ranged from $60 \%$ to $90 \%$ for seedlings produced in $110 \mathrm{~cm}^{3}$ tubes and from $75 \%$ to $85 \%$ for the ones produced in $280 \mathrm{~cm}^{3}$ (Table 5). According to Art. 8ㅜ, item 4.2 of the INEA resolution no 89 of June 2014 (RIO DE JANEIRO, 2014), concerning reforestation projects, it is acceptable a mortality rate per species up to $20 \%$ at four years after planting. In this context, at five months after planting, for seedlings produced in $110 \mathrm{~cm}^{3}$ tubes only the ones that received a CRF dose of $12 \mathrm{~kg} \cdot \mathrm{m}^{-3}$ presented a survival rate above $80 \%$. On the other hand, during the same period, considering seedlings produced in 280 $\mathrm{cm}^{3}$ tubes, just the ones that received application of fertilizer in the dose of $12 \mathrm{~kg} \cdot \mathrm{m}^{-3}$ presented survival rate below $80 \%$.

Results at twelve months after planting show that none of the treatments met the minimum survival rate of $80 \%$ (Table 5). The area presented a positive water balance (Figure 1) and excessive humidity during November and December, what combined with precipitation observed in January, February, March and April, favored the seedling survivals until May (5 months), when the first evaluation was undertook, showing that the planting was done in the right time of the year, the beginning of the rainy season. Nevertheless, the water deficit from May to September (Figure 1), caused by the shortage of precipitation during this period and the sandy clay loam soil, resulted in high mortality. At twelve months after planting the maximum survival rate for seedlings produced in $110 \mathrm{~cm}^{3}$ tubes was of $50 \%$ in the CRF dose of $6 \mathrm{~kg} \mathrm{~m}^{-3}$ and for the $280 \mathrm{~cm}^{3}$ tubes it was of $60 \%$ for the seedlings produced in the $3 \mathrm{~kg} \mathrm{~m}^{-3} \mathrm{CRF}$ dose.

Although seedlings were produced with appropriate management practices and showed good quality in the nursery, the establishment phase is crucial for the survival and growth after planting. The environmental conditions of the planting area were not adequate for this species, according to Carvalho (2003), Schizolobium parahyba occurs naturally in areas with none, low or moderate water deficit (dry season with no more than 4 months), also that sandy and or dry soils are inadequate for planting this species. In the present study, the climatic conditions provided accentuated water restriction, which combined with the sandy clay loam soil, resulted in low survival of seedlings. Thus, is possible to affirm that it is not recommended to plant Schizolobium parahyba in areas with sandy soils and large periods of water deficit.

Based on the results, Schizolobium parahyba seedlings produced in $280 \mathrm{~cm}^{3}$ tubes presented superior survival rate in comparison with the ones produced in $110 \mathrm{~cm}^{3}$, considering the averages of 71 and $80 \%$ at 5 months and 36 and $52 \%$ at twelve months after planting, respectively for 110 and $280 \mathrm{~cm}^{3}$. This result is probably due to the larger nutrient availability for the seedlings produced in $280 \mathrm{~cm}^{3}$ tubes. According to Keller et al (2009), for Atlantic Forest species, usually 
the root system growth is slow and nutrients absorption limited right after planting, thus the survival rate and the initial growth rely on the translocation of plants internal nutrients reserve.

\section{Table 5 - Survival rate and mean values for height and diameter of Schizolobium parahyba seedlings produced in two different volumes of plastic tubes and increasing controlled release fertilizer doses, at five and twelve months after planting in reforestation area, in São Francisco do Itabapoana, RJ state.}

Tabela 5 - Sobrevivência e crescimento inicial médio em altura e diâmetro para mudas de Schizolobium parahyba produzidas em dois volumes de tubetes e doses crescentes de fertilizante de liberação lenta, aos cinco e doze meses após plantio em área de reflorestamento em São

Francisco do Itabapoana, RJ.

\begin{tabular}{|c|c|c|c|c|c|c|c|}
\hline \multirow[t]{2}{*}{ Tube Volume } & \multicolumn{2}{|r|}{ Planting } & \multicolumn{2}{|c|}{---- 5 months ----- } & \multicolumn{3}{|c|}{ 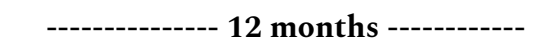 } \\
\hline & Dose & $\mathbf{H}(\mathbf{c m})$ & Surv. (\%) & $\mathbf{H}(\mathbf{c m})$ & Surv. (\%) & $\mathbf{H}(\mathbf{c m})$ & DGH $(\mathbf{m m})$ \\
\hline \multirow{5}{*}{$110 \mathrm{~cm}^{3}$} & 0 & 34.2 & 65 & 55.2 & 25 & 108.2 & 30.0 \\
\hline & 3 & 36.6 & 60 & 60.3 & 30 & 134.8 & 36.7 \\
\hline & 6 & 43.0 & 70 & 60.7 & 50 & 110.9 & 34.3 \\
\hline & 12 & 47.4 & 90 & 62.3 & 40 & 91.3 & 24.1 \\
\hline & Mean & 40.3 & 71.3 & 59.6 & 36.3 & 111.3 & 31.3 \\
\hline \multirow{5}{*}{$280 \mathrm{~cm}^{3}$} & 0 & 44.1 & 80 & 58.6 & 45 & 103.0 & 30.8 \\
\hline & 3 & 47.7 & 85 & 68.8 & 60 & 113.1 & 32.0 \\
\hline & 6 & 52.2 & 80 & 68.1 & 55 & 115.9 & 30.1 \\
\hline & 12 & 58.1 & 75 & 74.1 & 50 & 115.2 & 30.7 \\
\hline & Mean & 50.5 & 80.0 & 67.4 & 52.5 & 111.8 & 30.9 \\
\hline
\end{tabular}

Where: $\mathrm{H}$ = Height; Surv. = Survival rate; DGH = diameter at ground height.

There was no difference in height and DGH measurements for both tubes volumes and for increasing CRF doses (Table 5). Despite that no statistical difference was observed, at five months after planting, for both tubes, seedlings produced with the larger CRF dose $\left(12 \mathrm{~kg} \cdot \mathrm{m}^{-}\right.$ 3) presented superior height. However, height increment between planting and five months after, was superior for seedlings of both tubes in the CRF dose of $3 \mathrm{~kg} \cdot \mathrm{m}^{-3}$, which presented, respectively, 23.7 and $21.1 \mathrm{~cm}$. This result was also observed between planting and a twelvemonth evaluation, where seedlings of this same treatment presented, respectively for 110 and $280 \mathrm{~cm}^{3}$ tubes, 98.2 and $65.4 \mathrm{~cm}$ of height increment.

Despite inferior survival rate after planting, those seedlings produced in $110 \mathrm{~cm}^{3}$ tubes presented greater height increment than the ones produced in $280 \mathrm{~cm}^{3}$ tubes. At planting, in average values, seedlings from $110 \mathrm{~cm}^{3}$ tubes had $40.3 \mathrm{~cm}$ height, $10.2 \mathrm{~cm}$ smaller than the ones in $280 \mathrm{~cm}^{3}$ tubes. At twelve months after planting, such difference decreased to only 0.5 $\mathrm{cm}$. Similar post-planting results, were also observed by Keller et al. (2009) for Inga marginata, Jacaranda puberula and Zeyheria tuberculosa and by Abreu et al. (2015), for seedlings of Enterolobium contortisiliquum. According to these authors, the seedlings produced in smaller containers, under restriction to root system development, suffer a natural rustification at the nursery stage, due to reduced water and the nutrient offers, causing the development of tolerance mechanisms to site conditions and to contribute for growth after planting.

Climate conditions affected negatively the survival and growth of Schizolobium parahyba seedlings after planting. Considering the low seedling survival, it was not possible to conclude, 
combining both seedling production in the nursery and their planting in the reforestation site, what would be the adequate dose of CRF to provide better nursery management and quality seedlings. Nonetheless, on a planting site with better climate and soil conditions for Schizolobium parahyba the results could be different.

\section{Conclusions}

In the nursery, higher growth was observed for seedlings of Schizolobium parahyba produced in $280 \mathrm{~cm}^{3}$ plastic tubes. The most efficient doses of CRF was calculated to be $8.3 \mathrm{~kg}$ $\mathrm{m}^{3}$, considering this species and the substrate used in the study.

In consequence of five months of water deficit in a sandy clay loam soil, seedlings of Schizolobium parahyba from all treatments showed survival rates below $80 \%$ at twelve months after planting. The treatment that provided best survival rate $(60 \%)$ was the $280 \mathrm{~cm}^{3}$ plastic tube with $3 \mathrm{~kg} \mathrm{~m}^{-3}$ of CRF.

\section{References}

ABREU, A. H. M. et al. Urban solid waste in the production of Lafoensia pacari seedlings. Agriambi, Campina Grande, v. 21, n. 2, p. 83-87, 2017.

ABREU, A. H. M. et al. Produção de mudas e crescimento inicial em campo de Enterolobium contortisiliquum produzidas em diferentes recipientes. Floresta, Curitiba, v.45, n.1, p.141-150, mar. 2015.

BRACHTVOGEL, E. L.; MALAVASI, U. C. Volume do recipiente, adubação e sua forma de mistura ao substrato no crescimento inicial de Peltophorium dubium (Sprengel) Taubert em viveiro. Revista Árvore, Viçosa, v.34, n.2, p.223-232, abr. 2010.

CABREIRA, G. V. et al. Biossólido como componente de substrato para produção de mudas florestais. Floresta, Curitiba, v.47, n. 2, p. 165-176, 2017.

CARVALHO, P. E. R. Espécies arbóreas brasileiras: volume I. Colombo: Embrapa Florestas, 2003, 1039p.

CHINELATO, F. C. S. et al. Variabilidade genética em progênies de guapuruvu Schizolobium parahyba. Scientia Agropecuaria, Trujillo, v.5, n.2, p.71-76, jun. 2014.

EMBRAPA. Manual de análises químicas de solos, plantas e fertilizantes. Brasília: Embrapa Informação Tecnológica, 2009. 627p.

FERRAZ A. V.; ENGEL V. L. Efeito do tamanho de tubetes na qualidade de mudas de jatobá (Hymenaea courbaril L. Var. stilbocarpa (Hayne) Lee et Lang.), ipê-amarelo (Tabebuia chrysotricha (Mart. ex DC.) Sandl.) e guarucaia (Parapiptadenia rigida (Benth.) Brenan). Revista Árvore, Viçosa, v.35, n.3, p.413-423, jun. 2011.

FIGUEIRÓ, C. G.et al. Efeito do recipiente e do método de superação de dormência no crescimento de mudas de Schizolobium parahyba (Vell.) S. F. Blake. Enciclopédia Biosfera, Jandaia, v.14, n.25, p.490-497, jun. 2017.

GOMES J. M.; PAIVA H. N. Viveiros florestais (propagação sexuada). Viçosa: Editora UFV, 2006, 116 p.

GUERRINI, I.A.; TRIGUEIRO, R. M. Atributos físicos e químicos de substratos compostos por biossólidos e casca de arroz carbonizada. Revista Brasileira de Ciência do Solo, Viçosa, v.28, n.6, p.1069-1076, dez. 2004.

RIO DE JANEIRO. Instituto Estadual Do Ambiente. Resolução INEA no 89, de 03 de junho de 
2014. Diário Oficial do Estado do Rio de Janeiro, Rio de Janeiro, RJ, 05 de junho de 2014.

KELLER, L. et al. Sistemas de blocos prensados para a produção de mudas de três espécies arbóreas nativas. Revista Árvore, Viçosa, v.33, n.2, p.609-617, abr. 2009.

KÖPPEN, W. Das Geographische System der Klimate. In: KÖPPEN, W.; GEIGER, R. Handbuch der Klimatologie. Berlin: Gebrüder Bornträger, 1936, 44 p.

LELES, P. S. S. et al. Qualidade de mudas de quatro espécies florestais produzidas em diferentes tubetes. Floresta e Ambiente, Seropédica, v.13, n.1, p.69-78, set. 2006.

LISBOA, A. C. et al. Efeito do volume de tubetes na produção de mudas de Calophyllum brasiliense e Toona ciliata. Revista Árvore, Viçosa, v.36, n.4, p.603-609, ago. 2012.

MARSCHNER, H. Mineral nutrition of higher plants, London: Academic Press, 1995, 651 p.

MORAES, L. F. D. et al. Manual técnico para a restauração de áreas degradadas no Estado do Rio de Janeiro. Rio de Janeiro: Instituto de Pesquisas Jardim Botânico do Rio de Janeiro, 2013, 77 p.

NASCIMENTO, D. F. et al. Crescimento inicial de seis espécies florestais em diferentes espaçamentos. Cerne, Lavras, v. 18, n. 1, p. 159-165, mar. 2012.

RAIJ, B. et al. Análise química para avaliação da fertilidade de solos tropicais. Campinas: Instituto Agronômico, 2001. 285p.

ROSSA, U. B. et al. Fertilização de liberação lenta no crescimento de mudas de paricá em viveiro. Pesquisa Florestal Brasileira, Colombo, v.33, n.75, p.227-234, set. 2013b.

ROSSA, U. B. et al. Fertilizante de liberação lenta no desenvolvimento de mudas de Schinus terebinthifolius e Sebastiania commersoniana. Floresta, Curitiba, v. 43, n. 1, p. 93 - 104, mar. 2013 a.

SCHEER, M. B. et al. Composto de lodo de esgoto para a produção de mudas de Anadenanthera colubrina (Vell.) Brenan. Cerne, Lavras, v.18, n.4, p.613-621, dez. 2012.

SCHEER, M. B.; CARNEIRO, C.; SANTOS, K. G. Crescimento de mudas de Prunus brasiliensis (Cham. and Schltdl.) D. Dietr. em substratos à base de lodo de esgoto compostado e fertilizante mineral. Ciência Florestal, Santa Maria, v.22, n.4, p.739-747, 2012.

SENTELHAS, P. C.; PEREIRA, A. R.; MARIN, F. R. BHBRASIL: balanços hídricos climatológicos de 500 localidades brasileiras. Piracicaba, ESALQ, 1998, 7 p.

STÜPP, A. M. et al. Crescimento de mudas de Mimosa scabrella Benth em função de diferentes tamanhos de recipientes e doses de fertilizante. Ecologia e Nutrição Florestal, Santa Maria, v.3, n.2, p.40-47, ago. 2015.

TAIZ, L.; ZEIGER, E. Fisiologia vegetal. Porto Alegre: Artmed, 2009, 643 p.

THORNTHWAITE, C. W.; MATHER, J. C. The water balance. Centeron: Drexel Institute of Technology, 1955, $104 \mathrm{p}$. 